\title{
EFEKTIFITAS PEMBERIAN TABLET TAMBAH DARAH PADA REMAJA TERHADAP PENINGKATAN HEMOGLOBIN (Hb) DI STIKES MUHAMMADIYAH CIREBON
}

\author{
Tonasih, Siti Difta Rahmatika dan Ade Irawan \\ Sekolah Tinggi Ilmu Kesehatan Muhammadiyah Cirebon, 0231487677 \\ Email : asih_islamiyah@yahoo.co.id
}

\begin{abstract}
ABSTRAK
Salah satu upaya untuk memutus mata rantai terjadinya stunting, Wali Kota Cirebon menetapkan pencanangan "Hari Minum Tablet Tambah darah (TTD)" terhadap para siswa SMP/MTs dan SMA/SMK/MA setiap hari rabu di Sekolah. Kebijakan tersebut bertujuan untuk mempersiapkan generasi yang sehat, produktif dan berkualitas. Penelitian ini bertujuan mengetahui pengaruh pemberian TTD pada remaja putri terhadap peningkatan Haemoglobin ( $\mathrm{Hb}$ ) di STIKes Muhammadiyah Cirebon Tahun 2019. Metode Penelitian ini adalah quasi eksperimen, populasi mahasiswi di STIKes Muhammadiyah Cirebon dengan Total Sampling sebanyak 22 orang. Analisa data menggunakan analisis univariat dan analisis bivariat dengan paired $T$ test. Kadar hemoglobin pada responden sebelum diberikan tablet Fe didapatkan rata-rata kadar $\mathrm{Hb}$ sebesar $12.7 \mathrm{~g} / \mathrm{dl}$, sedangkan sesudah mengkonsumsi tablet Fe rata-rata kadar $\mathrm{Hb}$ sebesar $12.9 \mathrm{~g} / \mathrm{dl}$ dengan $P$ value 0,022 . Ada pengaruh pemberian tablet tambah darah pada remaja terhadap peningkatan $\mathrm{Hb}$ di STIKes Muhammadiyah Cirebon tahun 2019.
\end{abstract}

Kata kunci: anemia; tablet tambah darah; remaja putri

\begin{abstract}
One of the efforts to break the chain of stunting, the Mayor of Cirebon established the declaration of "Taking Fe Day)" to students of secondary school and high school every Wednesday at School. The policy is aimed to prepare a healthy, productive and qualified generation. This study was aimed to determine the effect of Fe on female teenagers in increasing hemoglobin $(\mathrm{Hb})$ at STIKes Muhammadiyah Cirebon in 2019. This study was a quasi-experimental, female student population at STIKes Muhammadiyah Cirebon with a total sampling of 22 people. Data analysis used univariate analysis and bivariate analysis of paired $\mathrm{T}$ tests. Hemoglobin levels in respondents before given Fe tablets obtained an average of $\mathrm{Hb}$ level is $12.7 \mathrm{~g} / \mathrm{dl}$, whereas after consuming Fe tablets an average $\mathrm{Hb}$ level is $12.9 \mathrm{~g} / \mathrm{dl}$ with a $\mathrm{P}$ value of 0.022 . There is an effect of giving Fe tablets to female teenagers in the increase of $\mathrm{Hb}$ at STIKes Muhammadiyah Cirebon in 2019.
\end{abstract}

Keywords: anemia;female teenagers; Fe tablets 


\section{LATAR BELAKANG}

Angka Kematian Ibu (AKI) dan Angka Kematian Bayi (AKB) di Indonesia masih tinggi, menurut Survei Demografi Kesehatan Indonesia (SDKI) pada tahun 2012 mencapai angka 359 per 100.000 Kelahiran Hidup (KH) dan Angka Kematian Bayi (AKB) mencapai 40 per $1000 \mathrm{KH}$ (Kemenkes RI, 2015). Berdasarkan target Sustainable Development Goals (SDGs) pada tahun 2030 diharapkan terjadi penurunan AKI menjadi sebesar 70 per $100.000 \mathrm{KH}$ dan AKB sebesar 12 per $1000 \mathrm{KH}$. (Kemenkes RI, 2015)

Menurut hasil riset Badan Pusat Statistik (BPS) mencatat bahwa AKI pada tahun 2016 sebesar 305 per $100.000 \mathrm{KH}$ dan AKB sebesar 25,5 per $1000 \mathrm{KH}$. (BPS, 2016). Menurut laporan Dinas Kesehatan Jawa Barat pada tahun 2016 disampaikan bahwa jumlah kasus kematian Ibu melahirkan karena kehamilan, persalinan, dan nifas terjadi penurunan tapi tidak signifikan dari 823 kasus pada tahun 2015 menjadi 780 kasus pada tahun 2016. (www.Pikiran Rakyat.com).

Menurut Menkes RI, penyebab langsung kematian ibu disebabkan oleh perdarahan, tekanan darah yang tinggi saat hamil (eklamsia), infeksi, persalinan macet dan komplikasi keguguran. Sedangkan penyebab langsung kematian bayi adalah Bayi Berat Lahir Rendah (BBLR) dan kekurangan oksigen (asfiksia). Penyebab tidak langsung kematian ibu dan bayi baru lahir adalah kondisi masyarakat seperti pendidikan, sosial ekonomi dan budaya. Kondisi geografi serta keadaan sarana pelayanan yang kurang siap ikut memperberat permasalahan. Beberapa hal tersebut, mengakibatkan kondisi 3 terlambat (terlambat mengambil keputusan, terlambat sampai di tempat pelayanan, dan terlambat mendapatkan pertolongan yang adekuat) dan 4 terlalu (terlalu tua, terlalu muda, terlalu banyak dan terlalu rapat jarak kelahiran). (www.depkes.go.id)

Penyebab kematian ibu salah satunya adalah perdarahan. Perdarahan yang terbanyak terjadi pada pascapersalinan yang salah satunya diakibatkan karena atonia uteri. Atonia uteri adalah uterus tidak berkontraksi dan lembek. Faktor predisposisi terjadinya atonia uteri antara lain multiparitas, partus lama, regangan uterus, solusio plasenta, dan anemia.

Masa remaja merupakan suatu fase perkembangan antara masa kanak dan masa dewasa; berlangsung antara usia 10 sampai 19 tahun. Masa remaja terdiri dari masa remaja awal (10-14 tahun). Masa remaja pertengahan (14-17 tahun) dan masa remaja akhir (17-19 tahun). Pada masa remaja, banyak terjadi perubahan baik biologis, psikologis maupun sosial. Tetapi umumnya proses pematangan fisik terjadi lebih cepat dari proses pematangan kejiwaan (psikososial).

Seorang remaja tidak lagi dapat disebut sebagai anak kecil, tetapi belum juga dapat dianggap sebagai orang dewasa. Di satu sisi ia ingin bebas dan mandiri, lepas dari pengaruh orang tua, di sisi lain pada dasarnya ia tetap membutuhkan bantuan, dukungan serta perlindungan orang-tua nya.

Menurut kesepakatan ICP pada tahun 1994, kesehatan reproduksi di tingkat internasional disepakati sebagai suatu keadaan sejahtera fisik, mental dan sosial secara utuh, tidak semata-mata bebas dari penyakit atau kecacatan dalam semua hal yang berkaitan dengan sistem reproduksi serta fungsi dan prosesnya.

Kesehatan reproduksi wanita adalah kemampuan seorang wanita untuk memanfaatkan alat reproduksinya dan mengatur kesuburannya (fertilitas) dapat menjalani kehamilan dan persalinan secara aman serta mendapatkan bayi tanpa risiko apapun dan selanjutnya mengembalikan kesehatan dalam batas normal.

Kesehatan reproduksi remaja sulit dipisahkan dari kesehatan remaja secara keseluruhan, karena gangguan kesehatan remaja akan menimbulkan gangguan pula pada sistem reproduksi. Beberapa keadaan yang berpengaruh buruk terhadap kesehatan remaja termasuk kesehatan reproduksi remaja antara lain masalah gizi, masalah pendidikan, masalah lingkungan dan pekerjaan, masalah seks dan seksualitas, masalah kesehatan reproduksi remaja.

Masalah gizi yang terjadi pada remaja antara lain anemia dan kurang energi kronis 
dan pertumbuhan yang terhambat pada remaja putri sehingga mengakibatkan panggul sempit dan risiko untuk melahirkan bayi berat lahir rendah di kemudian hari.

Anemia adalah berkurangnya haemoglobin $(\mathrm{Hb})$ dalam darah. $\mathrm{Hb}$ adalah komponen di dalam sel darah merah (eritrosit) yang berfungsi menyalurkan oksigen ke seluruh tubuh. Jika $\mathrm{Hb}$ berkurang, jaringan tubuh kekurangan oksigen. Oksigen diperlukan tubuh untuk bahan bakar proses metabolisme.

Ibu hamil mempunyai tingkat metabolisme tinggi misalnya untuk mengangkat jaringan tubuh janin, membentuknya menjadi organ, dan juga untuk memproduksi energi agar ibu hamil bisa tetap beraktifitas normal sehari-hari. Karena itu, ibu hamil lebih banyak memerlukan zat besi dibandingkan ibu yang tidak hamil.

Anemia merupakan masalah gizi yang sering ditemui di negara maju maupun berkembang dan menjadi masalah kesehatan masyarakat (Chakma et al. 2012). Salah satu kelompok umur yang rentan mengalami anemia adalah remaja (Tesfaye et al. 2015). Pada periode remaja (10-19 tahun), prevalensi anemia di negara berkembang adalah $27 \%$ dan $6 \%$ di negara maju (Dugdale 2001). Berdasarkan hasil Riskesdas tahun 2013, prevalensi anemia remaja di tingkat nasional sebesar 18,4\% (Kemenkes RI 2013).

Menurut World Health Organization (WHO) kadar haemoglobin $(\mathrm{Hb})$ sebagai indikator anemia untuk anak-anak dan wanita hamil $<11$ $\mathrm{g} / \mathrm{L}$ dan untuk wanita hamil < $11 \mathrm{~g} / \mathrm{L}$ dan untuk wanita tidak hamil $<12 \mathrm{~g} / \mathrm{L}$. Sedangkan anemia berat $<7 \mathrm{~g} / \mathrm{L}$ untuk anak-anak dan wanita tidak hamil < $8 \mathrm{~g} / \mathrm{L}(\mathrm{WHO}, 2011)$.

Prevalensi anemia untuk wanita hamil adalah 38,2 \% dan untuk wanita usia reproduksi adalah 29,4\%. Pemberian suplemen zat besi akan meningkatkan haemoglobin darah, rata 10,2 g/L pada wanita hamil dan 8,6 $\mathrm{g} / \mathrm{L}$ pada wanita hamil dan 8,6 g/L pada wanita tidak hamil. Sekitar 50\% dari anemia pada wanita bisa dihilangkan dengan suplementasi zat besi secara global. (WHO, 2011).

Pemerintah Indonesia sejak tahun 1997 telah menjalankan program pencegahan dan penanggulangan anemia gizi pada Wanita Usia Subur (WUS) dengan mengintervensi WUS lebih dini lagi, yaitu sejak usia remaja. Program ini bertujuan untuk mendukung upaya penurunan angka kematian ibu dengan menurunkan risiko terjadinya perdarahan akibat anemia pada ibu hamil (Depkes 2003). Pemberian TTD pada remaja putri yaitu 1 tablet/minggu dan 1 tablet/hari selama 10 hari ketika menstruasi (Depkes 2003).

Program Optimalisasi Pemberian Tablet Tambah Darah (TTD) pada Remaja Putri dan Wanita Usia Subur (WUS) di Kota Cirebon telah ditetapkan oleh Wali Kota Cirebon dalam upaya memutus mata rantai terjadinya stunting. Kebijakan tersebut bertujuan untuk mempersiapkan generasi yang sehat, produktif dan berkualitas. Wali Kota Cirebon menetapkan pencanangan "Hari Minum TTD" terhadap para siswa SMP/MTs dan SMA/SMK/MA setiap hari Rabu pada setiap minggu yang dilaksanakan di sekolah.

Tujuan pemberian suplementasi pada remaja putri untuk meningkatkan status gizi dan kesehatan remaja putri yang anemia; meningkatkan kadar hemoglobin, zat besi dan zinc dalam darah; menurunkan kejadian sakit, meningkatkan berat badan, tinggi badan dan Indeks Masa Tubuh (IMT). Anak-anak dan orang dewasa memerlukan Asam Folat untuk memproduksi sel darah merah dan mencegah anemia.

Berdasarkan hasil studi pendahuluan terhadap beberapa remaja putri di kota Cirebon masih banyak yang mengalami anemia karena defisiensi zat besi.Selain itu saat dilakukan wawancara dengan hasil yang menunjukkan bahwa mereka tidak mengetahui dengan pasti pengertian anemia, normalnya kadar hemoglobin, penyebab anemia dan dampak yang akan ditimbulkan.

Berdasarkan fenomena tersebut, peneliti merasa perlu melakukan penelitian dengan tujuan menganalisis pengaruh pemberian tablet tambah darah terhadap peningkatan kadar haemoglobin pada remaja putri di STIKes Muhammadiyah Cirebon. 


\section{METODE}

Desain penelitian yang digunakan adalah quasi eksperimen, dimana ada perlakuan pemberian tablet tambah darah selama 2 bulan kepada remaja putri (mahasiswi) di STIKes Muhammadiyah Cirebon yang sebelumnya diperiksa kadar haemoglobinnya, setelah pemberian tablet tambah darah selama 2 bulan kadar haemoglobinnya akan diperiksa kembali. Dalam penelitian ini yang menjadi populasi adalah seluruh siswi di STIKes Muhammadiyah Cirebon prodi kebidanan berjumlah 163 orang. Teknik pengambilan sampel dalam penelitian ini menggunakan Total Sampling dengan menggunakan kriteria inklusi dan eksklusi sehingga didapatkan sampel sebanyak 22 orang.

\section{HASIL}

\section{Tabel 1. Distribusi Frekuensi Responden Menurut Kejadian Anemia}

\begin{tabular}{lcccc}
\hline \multirow{2}{*}{ Kejadian } & \multicolumn{2}{c}{$\begin{array}{c}\text { Sebelum } \\
\text { Konsumsi }\end{array}$} & \multicolumn{2}{c}{$\begin{array}{c}\text { Sesudah } \\
\text { Konsumsi }\end{array}$} \\
\cline { 2 - 5 } & $\mathbf{f}$ & $\%$ & $\mathbf{F}$ & $\%$ \\
\hline Anemia & 2 & 0,1 & 1 & 0,04 \\
Tidak Anemia & 20 & 90,9 & 21 & 99,96 \\
Jumlah & $\mathbf{2 2}$ & 100 & 22 & 100 \\
\hline
\end{tabular}

Berdasarkan tabel 1 terlihat bahwa sebelum mengkonsumsi tablet $\mathrm{Fe}$ terdapat 2 orang responden berada pada kategori anemia yaitu sebanyak $01 \%$, dan setelah mengkonsumsi tablet Fe terdapat 1 orang responden yang mengalami anemia sebanyak 1 orang $(0,04 \%)$

Tabel 2. Distribusi Frekuensi Responden Menurut Umur

\begin{tabular}{lcc}
\hline \multicolumn{1}{c}{ Usia } & $\mathbf{f}$ & \% \\
\hline Remaja Awal & 0 & 0 \\
Remaja Tengah & 0 & 0 \\
Remaja Akhir & 22 & 100 \\
\hline Jumlah & $\mathbf{2 2}$ & 100 \\
\hline
\end{tabular}

Berdasarkan distribusi frekuensi responden menurut umur pada tabel diatas, semua responden merupakan remaja akhir sebanyak 22 orang (100\%).

Tabel 3. Distribusi Frekuensi Responden Menurut Tempat Tinggal

\begin{tabular}{lcc}
\hline Tempat Tinggal & $\mathbf{f}$ & $\%$ \\
\hline Asrama & 22 & 100 \\
Kost & 0 & 0 \\
Rumah orang Tua & 0 & 0 \\
Jumlah & $\mathbf{2 2}$ & $\mathbf{1 0 0}$ \\
\hline
\end{tabular}

Berdasarkan distribusi frekuensi responden menurut tempat tinggal pada tabel di atas, semua responden tinggal di Asrama.

Tabel 4. Pengaruh pemberian Tablet Fe Terhadap Peningkatan Kadar $\mathrm{Hb}$

\begin{tabular}{lccc}
\hline Kejadian & N & Means & $\begin{array}{c}\text { P } \\
\text { value }\end{array}$ \\
\hline Hb Sebelum & 22 & 12.7 & 0,022 \\
Hb Sesudah & 22 & 12.9 & \\
\hline Jumlah & 22 & & 100 \\
\hline
\end{tabular}

Berdasarkan data pada tabel 4 dapat diketahui bahwa kadar hemoglobin pada responden sebelum diberikan tablet $\mathrm{Fe}$ didapatkan rata-rata sebesar $12.7 \mathrm{~g} / \mathrm{dl}$, sedangkan sesudah mengkonsumsi tablet $\mathrm{Fe}$ rata-rata sebesar $12.9 \mathrm{~g} / \mathrm{dl}$. dan diketahui bahwa nilai signifikan $P$ value yang diperoleh lebih kecil dari 0.05 sehingga Hipotesis diterima.

\section{PEMBAHASAN}

\section{Gambaran Responden Berdasarkan Anemia}

Hasil penelitian menunjukkan sebagian besar mahasiswa di STIKes Muhammadiyah tidak mengalami anemia. Hal ini tidak sesuai dengan penelitian yang dilakukan oleh Giyanti (2015) yang mengatakan bahwa dalam penelitiannya mayoritas remaja putri mengalami anemia.

Anemia merupakan masalah kesehatan yang belum tuntas ditangani, prevalensi kejadian anemia pada remaja perempuan di 
Indonesia masih tinggi yaitu sebesar $22 \%$. Dampak dari kejadian anemia mungkin tidak dapat langsung terlihat, tetapi dapat berlangsung lama dan memengaruhi kehidupan remaja selanjutnya. Anemia pada remaja dapat berdampak panjang untuk dirinya dan juga untuk anak yang ia lahirkan kelak. Keadaan anemia yang berlanjut hingga dewasa dan saat perempuan tersebut hamil, dapat menimbulkan resiko terhadap bayinya seperti kelahiran prematur, dan berat bayi lahir rendah (BBLR).

Remaja mempunyai resiko tinggi mengalami anemia karena defisiensi zat besi. Hal ini disebabkan karena pada fase ini remaja mengalami pertumbuhan yang pesat disertai berbagai perubahan hormonal menjelang fase kedewasaan. Remaja membutuhkan sejumlah besar nutrisi terutama zat besi yang di gunakan untuk mengangkut oksigen. Zat besi yang tidak mencukupi memicu terjadinya anemia. (Giyanti, 2015)

Pada wanita zat besi yang dikeluarkan dari badan lebih banyak dari laki-laki. Setiap bulan wanita mengalami menstruasi, dan setiap periode menstruasi dikeluarkan zat besi rat-rata sebanyak $28 \mathrm{mg} /$ periode. Sehingga wanita memiliki resiko lebih besar mengalami anemia daripada laki-laki. (Herdata, 2000)

Menurut peneliti Mayoritas responden tidak mengalami anemia kemungkinan dikarenakan pola makan yang baik, saat responden tinggal di asrama dan sebelumnya sudah sering mengkonsumsi tablet tambah darah ketika haid.

\section{Gambaran Responden Berdasarkan Tempat Tinggal}

Berdasarkan penelitian yang sudah dilakukan didapatkan bahwa seluruh responden tinggal di asrama yaitu sebanyak 22 mahasiswa (100\%). Program asrama sebagai sebagai sarana pembinaan sosial akan menciptakan motivasi belajar yang lebih baik daripada mahasiswa yang tidak tinggal di asrama. Karena mahasiswa yang tinggal di asrama lebih mudah berinteraksi dengan teman, dosen, maupun dengan orang lain. (Martini, 2014)
Mahasiswa yang tinggal di asrama, harus hidup jauh dari orang tua dan mematuhi peraturan yang ada. Walau mereka jauh dengan orang tua bukan berarti selama diasrama mereka tidak didampingi dalam proses belajar mengajar. Diasrama terdapat pendamping mahasiswa yang bertugas untuk mendampingi siswa serta mengingatkan siswa untuk mengikuti kegiatan yang sudah ditetapkan guna meningkatkan prestasi belajar. (Siswaningtyas, 2009).

STIKes Muhammadiyah Cirebon sebagai salah satu yang menyediakan asrama bagi mahasiswanya, dan mewajibkan mahasiswa D3 prodi Kebidanan untuk tinggal di Asrama sampai dengan tahun 2019. Perubahan lingkungan dan kebiasaan sehari-hari dari semula tinggal dirumah bersama keluarga menjadi tinggal diasrama seringkali membuat stress sebagian mahasiswa. (Sarwa, 2014)

Menurut Penelitian yang dilakukan Sarwa (2014) menyatakan bahwa sesudah tinggal di asrama status gizi mahasiswa berada pada status normal, sehingga Marwa menyimpulkan bahwa standar menu yang telah diberikan pada mahasiswa di asrama telah memberikan asupan gizi yang baik untuk mendukung aktivitas yang harusdilaksanakan mahasiswa di asrama maupun di kampus.

\section{Gambaran Responden Berdasarkan Umur}

Berdasarkan distribusi frekuensi responden menurut umur pada tabel 2 di atas, semua responden merupakan remaja akhir (100\%). Remaja adalah suatu fase perkembangan antara masa kanak dan masa dewasa; berlangsung antara usia 10 sampai 19 tahun. Masa remaja akhir rata rata remaja sudah memasuki sekolah menengah tingkat atas dan saat sudah berada di kelas terakhir maka sudah bisa dianggap hampir dewasa dan berada pada ambang perbatasan untuk masuk dalam dunia kerja orang dewasa.

Menurut WHO (Sarwono, 2011) Remaja merupakan suatu masa dimana individu berkembang dari saat ia pertama kali menunjukan tanda-tanda seksual sekundernya sampai saat ia mencapai kematangan seksual, memiliki perkembangan psikologis dan 
identifikasi dari kanak-kanak menjadi dewasa, terjadi peralihan dari ketergantungan sosial ekonomi atau mandiri.

Menurut Hurlock (1990) Pada Remaja akhir, merupakan masa dimana individu sudah mencapai transisi perkembangan yang lebih mendekati masa dewasa. Pada masa ini terjadi proses perkembangan meliputi perubahanperubahan yang berhubungan dengan orang tua dan cita-cita mereka, dimana pembentukan cita-cita merupakan proses pembentukan orientasi masa depan. Jadi masa ini merupakan masa penutup dari masa remaja atau pemuda.

Menurut Agus Salim (2010) masa remaja ini sudah mulai stabil dan mantap, ia ingin hidup dengan modal keberanian, anak mengenal aku-nya, mengenal arah hidupnya, serta sadar akan tujuan yang dicapainya, pendiriannya sudah mulai jelas dengan cara tertentu. sikap kritis sudah semakin nampak, dan dalam hal ini sudah mulai aktif dan objektif dalam melibatkan diri ke dalam kegiatan-kegiatan dunia luar. Juga dia sudah mulai mencoba mendidik diri sendiri sesuai pengaruh yang diterimanya. Maka dalam hal ini terjadi pembangunan yang esensial terhadap pandangan hidupnya, dan masa ini merupakan masa berjuang dalam menentukan bentuk/corak kedewasaannya.

Krori (2012) menyatakan bahwa perubahan sosial yang penting pada masa remaja mencakup meningkatnya pengaruh teman sebaya, pola perilaku sosial yang baru, munculnya nila-nilai baru dalam memilih teman dan pemimpin serta nilai dalam penerimaan sosial.

\section{Pengaruh Pemberian Tablet Fe Terhadap Peningkatan Kadar $\mathrm{Hb}$}

Berdasarkan penelitian yang telah dilakukan didapatkan hasil statistik menyatakan kadar hemoglobin pretest dan posttest konsumsi tablet Fe dengan uji Paired t-test diperoleh hasil $P$ value $=0.002<\alpha(0.05)$, sehingga hasil uji statistik menunjukan bahwa hipotesis diterima dan bahwa ada perbedaan secara bermakna peningkatan kadar hemoglobin sebelum dan sesudah diberikan tablet Fe.

Hasil penelitian ini sejalan dengan penelitian yang telah dilakukan oleh Putri Ardhana BE, dkk (2012) yang memberikan intervensi dengan suplementasi Fe dan Zinc menyatakan bahwa pada kadar $\mathrm{Hb}$ sebelum dan sesudah suplementasi memiliki pengaruh positif terhadap peningkatan kadar $\mathrm{Hb}$ dengan nilai signifikan $(p=0.000)$.

Selain itu penelitian yang dilakukan oleh Ahmady, dkk (2016) dengan intervensi yang dilakukan pada responden untuk mengkonsumsi tablet Fe bahwa hasil uji statistik menunjukkan terdapat perbedaan kadar $\mathrm{Hb}$ sebelum dan sesudah intervensi pada kelompok perlakuan $(p=0.000)$. Hasil uji statistik didapatkan bahwa dalam penelitian ini terdapat pengaruh konsumsi tablet Fe terhadap peningkatan kadar hemoglobin pada remaja putri di SMA 2 Ngaglik Sleman. Penelitian ini menunjukkan bahwa ada peningkatan kadar hemoglobin setelah mengkonsumsi tablet Fe. Intervensi yang diberikan pada responden dengan mengkonsumsi tablet $\mathrm{Fe}$ sangat membantu untuk menanggulangi anemia zat besi (IDAI, 2011).

Pentingnya pemberian zat besi ini kepada seseorang yang sedang mengalami anemia defiseinsi besi dan tidak ada gangguan absorpsi maka dalam 7-10 hari kadar kenaikan hemoglobin bisa terjadi sebesar 1,4 $\mathrm{mg} / \mathrm{KgBB} /$ hari (Haryanto, 2006). Adapun faktor yang mempengaruhi peningkatan kadar hemoglobin pada remaja putri yaitu usia, frekuensi mentruasi, status gizi, pola makan, jenis makanan yang dikonsumsi, konsumsi tablet Fe dan aktivitas fisik. Faktor lain yang dapat diketahui dalam mempengaruhi kenaikan kadar hemoglobin yaitu siswi putri mengkonsumsi tablet Fe yang telah diberikan peneliti selama 1 bulan (30 hari) dan tetap mengkonsumsi selama menstruasi.

Hal ini dapat dibuktikan dalam teori yang mengatakan bahwa pemberian tablet $\mathrm{Fe}$ ini kepada remaja putri sangat bermanfaat pada keadaan haid, dikarenakan saat itu bisa terjadi kehilangan besi akibat perdarahan. Karena haid rata-rata mengeluarkan darah $60 \mathrm{ml}$ perbulan yang sama dengan $30 \mathrm{mg}$ besi, sehingga perempuan memerlukan tablet tambah darah satu miligram perhari agar keseimbangan tetap terjaga (Depkes, 2008).

Mengkonsumsi tablet Fe dapat mengobati wanita dan remaja putri yang mengalami 
anemia, meningkatkan kemampuan belajar, meningkatkan status gizi dan kesehatan remaja (Sani R, 2014). Mengkonsumsi tablet Fe dapat dibarengi dengan makanan atau minuman yang mengandung vitamin $C$ atau jus jeruk yang lebih cepat menyerap zat besi atau bersaman dengan makan daging, ikan, ayam sehingga dapat menstimulasi asam lambung.

Saat mengkonsumsi tablet tambah darah tidak diperbolehkan makan atau minum yang mengandung alkohol, teh. Kopi atau buahbuahan yang mengandung alkohol seperti durian, tape, nanas, mangga dikarenakan dapat menurunkan penyerapan zat besi dalam tubuh sehingga manfaatnya menjadi berkurang. Untuk mengurangi gejala mual dan muntah waktu yang tepat minum tablet $\mathrm{Fe}$ setelah makan malam atau menjelang tidur (Depkes, 2008).

Menurut peneliti pemberian tablet Fe pada remaja putri sangat dibutuhkan guna memenuhi kebutuhan zat gizi tubuh khususnya peningkatan zat besi dan sebagai upaya pencegahan stunting serta bentuk untuk persiapan pra nikah, kehamilan. Namun berdasarkan wawancara dengan remaja mayoritas mereka tidak teratur dalam mengkonsumsi tablet Fe dikarenakan setelah mengkonsumsi merasa mual dan konstipasi.

\section{KESIMPULAN DAN SARAN}

Ada Pengaruh Pemberian Tablet Tambah Darah pada Remaja Putri Setiap Hari Rabu terhadap Peningkatan Kadar Haemoglobin $(\mathrm{Hb})$ Di STIKes Muhammadiyah Cirebon Tahun 2019. Bagi Remaja putri diharapkan tetap mengkonsumsi tablet $\mathrm{Fe}$ secara teratur di kehidupan sehari-hari sehingga dapat memenuhi kebutuhan zat gizi yang diperlukan oleh tubuh khususnya peningkatan zat besi dan sebagai bentuk untuk persiapan pra nikah, kehamilan dan persalinan.

\section{REFERENSI}

Ahmady, dkk. 2016. Penyuluhan Gizi dan Pemberian Tablet Besi Terhadap Pengetahuan dan Kadar Hemoglobin Siswi Sekolah Menengah Atas Negeri di Mamuju. Jurnal Kesehatan Manarang Vol. 2 No.1 Juli 2016 ISSN: 2443-386

Arikunto, S. 2006. Prosedur Penelitian Suatu Pendekatan Praktik Edisi VI. Jakarta: Rineka Cipta

Cahyaningtyas, Dwi Kartika. 2017. Pengaruh Konsumsi Tablet Fe dengan Peningkatan Kadar Hb pada Remaja Putri di SMA 2 Ngaklik Kabupaten Sleman

Dalilay, Agus Salim. 2010. Diktat Psikologi Perkembangan. STAIN PSP

Depkes RI. 2008. Program Penanggulangan Anemia Gizi Pada Wanita Usia Subur (WUS) dan Remaja Putri, Jakarta Direktorat Gizi Masyarakat. 2018. Anemia Pada Remaja. (Depkes.go.id diakses pada 16 Agustus 2019 pkl 15.00)

Djaelani, Ahmad. 2000. IImu Gizi untuk Mahasiswa Profesi di Indonesia. Jakarta: Dian Rakyat

Giyanti, Fitri. 2015. Pengaruh Pemberian Tablet Fe terhadap Kenaikan kadar Hb Remaja Putri dengan Anemia di SMK Negeri 1 Bonjong Gunung Kidul Yogyakarta. (Digilib.unisa.ac.id diakses pada 27 Agustus 2019 pkl 17.00)

Gunatmaningsih, Dian. 2007. Faktor-Faktor yang Berhubungan dengan Kejadian Anemia pada Remaja Putri di SMA N 1 Jatibarang Kabupaten Brebes. (http:lib.unnes.ac.id diakses 19 Agustus 2019 pkl. 10.00)

Guyton dan Hall. 1997. Fisiologi Kedokteran. Jakarta: EGC

Haryanto, dkk. 2006. Buku Ajar Penyakit Dalam Edisi 4, Departemen IImu Penyakit Dalam Fakultas Kedokteran Indonesia. Jakarta.

Herdata, Heru Noviat. 2000. Pengaruh Suplemen Besi pada Remaja Putri Anemia Terhadap Pertumbuhan \& Tingkat Kesegaran Jasmani. Unnes: Semarang

Herlina. 2013. Mengatasi Masalah Anak dan Remaja Melalui Buku. : Bandung: Pustaka Cendekia Utama 
Hurlock. 1990. Depelopment Physcology a Lifespan Approach. (Terjemahan oleh Istiwidayanti). Jakarta: Erlagunarso

IDAI. 2011. Rekomendasi IDAI Suplementasi Besi Untuk Anak, Jakarta: Badan Penerbit IDAI.

I Dewa Nyoman S. 2001. Penilaian Status Gizi. Jakarta: EGC

Kemenkes RI. 2013. Pelayanan Kesehatan Ibu di Fasilitas Kesehatan Dasar dan Rujukan. Pedoman Bagi Tenaga Kesehatan. Edisi Pertama. Jakarta

Martini. 2014. Pengaruh Program Asrama Terhadap Motivasi Belajar ditinjau dari Kecerdasan Emosi. (uns.ac.id diakses 27 Agustus 2019 pkl 19.00)
Mary E. Beck. 2000. IImu Gizi dan Diet Hubungan dengan Penyakit-penyakit untuk Perawat Dokter. Yogyakarta: Yayasan Ensentia Medica

Notoatmodjo, S. 2005. Metode Penelitian Kesehatan. Jakarta: Rineka Cipta

Nuraeni, Rini. dkk. 2019. Peningkatan Kadar Hemoglobin melalui Pemeriksaan dan Pemberian Tablet Fe Terhadap Remaja yang Mengalami Anemia Melalui "Gerakan Jumat Pintar". Jurnal Pengabdian kepada $\begin{array}{lll}\text { Masyarakat UGM Vol.5, No.2 } & \end{array}$ (https://jurnal.ugm.ac.id > jpkm > article > download diakses 6 Desember 2019 pkl 15.00) 